J. Dairy Sci. 86:2170-2177

(c) American Dairy Science Association, 2003.

\section{Effects of Increasing Dietary Protein on Nutrient Utilization in Heifers ${ }^{1}$}

\author{
M. T. Gabler ${ }^{2}$ and A. J. Heinrichs \\ Department of Dairy and Animal Science \\ The Pennsylvania State University, University Park, PA 16802
}

\begin{abstract}
Four prepubertal Holstein heifers, average age 146.0 $\pm 3.6 \mathrm{~d}$ and $152.8 \pm 8.6 \mathrm{~kg}$ of body weight (BW), fitted with rumen cannulae were used to evaluate increasing levels of dietary protein with a constant metabolizable energy intake on rumen ammonia $\mathrm{N}$ concentrations, $\mathrm{N}$ balance, total tract apparent digestibility, and urinary excretion of purine derivatives in a $4 \times 4$ Latin square design with $20 \mathrm{~d}$ periods. Heifers were fed dietary crude protein levels (CP) of 11.9, 16.7, 18.1, and $20.1 \% \mathrm{CP}$ with similar amounts of metabolizable energy (ME) (2.6 Mcal per kg of dry matter) at $2.0 \%$ BW as dry matter intake. Resulting protein to $\mathrm{ME}$ ratios (CP:ME) were 45.0, 63.3, 69.4, and $77.3 \mathrm{~g}$ of dietary CP per Mcal of ME. Rumen ammonia $\mathrm{N}$ and plasma urea nitrogen increased as CP level increased. Rumen $\mathrm{pH}$, volatile fatty acids, and the acetate-to-propionate ratio were not affected with increasing CP levels. Greater urinary $\mathrm{N}$ excretion resulted in an increase in total $\mathrm{N}$ excretion with increasing CP levels. Apparent dry matter digestibility was similar for all diets, while apparent total tract $\mathrm{N}$ digestibility was lowest for the $11.9 \% \mathrm{CP}$ level. Microbial $\mathrm{N}$ calculated from urinary excretion of purine derivatives increased with increasing CP levels. Holstein heifers between 153 and $196 \mathrm{~kg}$ consuming a diet at $2.0 \% \mathrm{BW}$ as dry matter intake containing a CP level of $16.7 \%$ achieved a better synergistic relationship of dietary protein to energy (CP:ME of $63.3 \mathrm{~g}$ of CP per $\mathrm{Mcal}$ of ME) than the diets lower or higher in $\mathrm{CP}$ that were studied.
\end{abstract}

(Key words: heifer metabolism, $\mathrm{N}$ balance, protein-toenergy ratio)

Abbreviation key: F:C = forage-to-concentrate ratio, $\mathbf{M E}=$ metabolizable energy, $\mathbf{P D}=$ purine derivatives, PUN = plasma urea nitrogen .

\footnotetext{
Received May 16, 2002.

Accepted December 6, 2002.

Corresponding author: A. J. Heinrichs; e-mail: ajh@psu.edu.

${ }^{1}$ This research was a component of NC-119, Dairy Herd Management Strategies for Improved Decision Making and Profitability.

${ }^{2}$ Current address: ADM Alliance Nutrition, P.O. Box 44307, Madison, WI 53744.
}

\section{INTRODUCTION}

Efficient utilization of nutrients is of importance in ruminant nutrition. Poor utilization of nutrients can be costly, resulting in increased feeding cost and nutrient management concerns. Oldham (1984) stated that the interrelationship between dietary protein and carbohydrates within the rumen and ruminant body can have tremendous effects on the overall pattern of nutrient use. Excess dietary protein or carbohydrates can lead to an imbalance resulting in a lack of efficient utilization of dietary nutrients and poor microbial protein production (Nocek and Russell, 1988). Consequently, the relative amounts of dietary protein and carbohydrate intake are likely to determine the net efficiency of absorbed nutrients (Oldham, 1984).

Limited data are available for growing dairy heifers concerning rumen fermentation, microbial protein yield, and utilization of nutrients. Veira et al. (1980a, 1980b) utilizing a 146-kg BW male Holstein calves, evaluated dietary protein utilization of diets containing increasing levels of dietary protein $(10.2,12.2,14.1$, and $16.1 \% \mathrm{CP}$ ) in two separate experiments. Rumen ammonia $\mathrm{N}$ concentrations increased linearly, while rumen $\mathrm{pH}$ and VFA concentrations were not affected by CP levels (Veira et al., 1980a). Total tract apparent $\mathrm{DM}$ and $\mathrm{N}$ digestibility increased linearly (ranging from 71.1 to $75.1 \%$ and 61.6 to $72.2 \%$, respectively) with increasing levels of CP (Veira et al., 1980b). Estimated rumen microbial protein efficiency was highest at the 14.1\% CP level (Veira et al., 1980a).

Restricted-fed Holstein heifers increased feed efficiency and structural growth when dietary protein intake increased (12.0, 15.2, 17.4, and 19.7\% CP), whereas metabolizable energy (ME) intake remained constant (2.6 Mcal/kg of DM) (Gabler and Heinrichs, 2003). The objective of the current study was to elucidate the effect of increasing levels of dietary protein with a constant $\mathrm{ME}$ intake on rumen ammonia $\mathrm{N}$ concentrations, $\mathrm{N}$ balance, total tract apparent digestibility, and urinary excretion of purine derivatives (PD) in prepubertal Holstein heifers between 153 and $196 \mathrm{~kg}$ of BW. 


\section{MATERIALS AND METHODS}

Four prepubertal Holstein heifers at $115.0 \pm 3.0 \mathrm{~d}$ of age were fitted with rumen jarrets $(2.54 \mathrm{~cm}$ i.d., Macam Rubber, Baulkham Hills, Australia). Surgery was performed under local anesthesia following standard surgical procedures (Pennsylvania State University Institutional Animal Care and Use Committee). Heifers were allowed to recover for $30 \mathrm{~d}$ before initiation of the experiment. During the recovery period heifers were fed a ration meeting NRC (1989) recommendations for 0.80 $\mathrm{kg} / \mathrm{d}$ rate of gain. Before the start of the experiment, heifers received larger rumen cannulae $(3.81 \mathrm{~cm}$ i.d., Bar Diamond, Parma, ID). Heifers were individually housed in tie stalls located in a temperature-controlled barn with artificial ventilation. Heifers had free access to water at all times and were released $3 \mathrm{~h}$ postfeeding for approximately $2 \mathrm{~h} / \mathrm{d}$ to an outdoor paved exercise lot except on intensive sampling days.

Heifers at $146.0 \pm 3.6 \mathrm{~d}$ of age and $152.8 \pm 8.6 \mathrm{~kg}$ of $\mathrm{BW}$ were randomly assigned to one of four treatment rations in a $4 \times 4$ Latin square design. Each experimental period was $20 \mathrm{~d}$ in length, consisting of a 10-d adaptation period and a 10-d sampling period. In a recent growth trial by Gabler and Heinrichs (2003) with similar BW heifers and treatment rations, a ration DMI of $2.0 \%$ of BW was required to achieve a desired $0.80 \mathrm{~kg} /$ $\mathrm{d}$ rate of gain. Therefore, the present study was designed to investigate the effects of similar treatment rations as Gabler and Heinrichs (2003) on nutrient utilization, where DMI of treatment rations was set at $2.0 \%$ of BW.

Body weight was recorded on two consecutive days, $3 \mathrm{~h}$ postfeeding, every $10 \mathrm{~d}$ to determine the quantity of treatment ration offered for the next $10 \mathrm{~d}$. Heifers were individually fed once daily at $0900 \mathrm{~h}$. Treatment ration refusals were never present. At the conclusion of the fourth and last consecutive experimental period final BW was $196.0 \pm 14.3 \mathrm{~kg}$.

Treatment rations contained 11.9, 16.7, 18.1, and 20.1\% CP with similar amounts of ME (NRC, 1996) (2.6 Mcal of $\mathrm{ME} / \mathrm{kg}$ of $\mathrm{DM}$ ) across all treatment rations. Therefore, treatment rations contained CP:ME of 45.0, 63.3, 69.4, and $77.3 \mathrm{~g}$ of CP per Mcal of ME.

\section{Sample Collection, Sample Analysis, and Calculations}

Samples of treatment rations and forages were collected every other day during the experiment. Every $10 \mathrm{~d}$, portions of three samples of treatment rations and forages were dried for determination of treatment ration and forage $\mathrm{DM}$ with adjustment of the treatment ration to achieve accurate daily DMI as a percent of BW.
The remaining portions of the treatment ration and forage samples were frozen $\left(-20^{\circ} \mathrm{C}\right)$ until compositing at the conclusion of each experimental period. Composited treatment rations for each experimental period were analyzed for determination of particle size (Lammers et al., 1996), DM, CP (AOAC, 1990), soluble CP (Krishnamoorthy et al., 1982), RDP (Krishnamoorthy et al., 1983), total NSC (Smith, 1981; modified to use ferricyanide as a colorimetric indicator), starch (Holm et al., 1986), sugar (Dubois et al., 1956), and NDF and ADF $\left(\mathrm{ANKOM}^{200}\right.$ Fiber Analyzer, ANKOM Technology Corporation, Fairport, NY). Analysis for $\mathrm{Ca}, \mathrm{P}, \mathrm{Mg}$, and $\mathrm{K}$ content of treatment rations were determined by AOAC (1990). Composited forage samples for each experimental period were analyzed for determination of DM, CP, $\mathrm{NDF}$, and $\mathrm{ADF}$.

Samples of ventral sac rumen fluid were obtained via hand vacuum pump just before feeding $(0 \mathrm{~h})$ and 0.5 , $1,1.5,2,2.5,3,4,6,8,12,16$, and $23.5 \mathrm{~h}$ postfeeding on d 11 of each experimental period. Rumen fluid $\mathrm{pH}$ was recorded immediately ( $\mathrm{pH}$ meter, model M90, Corning Inc., Corning, NY) followed by a $15-\mathrm{ml}$ subsample preserved by addition of $3 \mathrm{ml}$ of $25 \%$ metaphosphoric acid and frozen $\left(-20^{\circ} \mathrm{C}\right)$ until analysis. Samples were later centrifuged at $4000 \times g$ for $30 \mathrm{~min}$ at $4^{\circ} \mathrm{C}$, repeated 3 times, to obtain clear supernatant. The supernatant was analyzed for rumen ammonia $\mathrm{N}$ using a phenolhypochlorite assay (Broderick and Kang, 1980) and molar concentrations of VFA by gas chromatography (Yang and Varga, 1989).

Blood samples were obtained through a left jugular vein catheter just before feeding $(0 \mathrm{~h})$ and $0.5,1,1.5$, $2,2.5,3,3.5,4,5,6,7,8,10,12,18$, and $23.5 \mathrm{~h}$ postfeeding on d 13 of each experimental period. Blood samples were stored and cooled in tubes containing citrate as an anticoagulant. Plasma samples were aspirated after centrifugation $(4000 \times g)$ and stored at $4.5^{\circ} \mathrm{C}$ for analysis the same day. Plasma samples were analyzed for urea N (procedure no. 0580; Standbio Laboratory Inc., San Antonio, TX).

Total collection of urine and feces took place from $d$ 17 to 20 . Urinary catheters (\#14 French balloons; Rusch Inc., Duluth, GA) were inserted before feeding on d 17 and removed at the conclusion of $d 20$. Urine samples were collected into a container with $80 \mathrm{ml}$ of $12 \mathrm{~N}$ hydrochloric acid to keep the $\mathrm{pH}$ below 3 . Feces were collected through a grated floor. Every $24 \mathrm{~h}$, total collection of urine and feces was weighed and recorded. A 1-L subsample of urine and the entire sample of feces were stored each $24 \mathrm{~h}$. Urine subsamples and feces were frozen $\left(-20^{\circ} \mathrm{C}\right)$ until analysis. Fecal samples were dried at $55^{\circ} \mathrm{C}$ for $72 \mathrm{~h}$ and ground through a 1-mm screen (Wiley mill, Arthur H. Thomas, Philadelphia, PA). Before analysis, dried ground feces and urine composites 
Table 1. Ingredient and nutrient compositions of the treatment rations (DM basis).

\begin{tabular}{|c|c|c|c|c|c|}
\hline & \multicolumn{4}{|c|}{ Dietary protein level (\% CP) } & \multirow[b]{2}{*}{$\mathrm{SE}$} \\
\hline & 11.9 & 16.7 & 18.1 & 20.1 & \\
\hline \multicolumn{6}{|l|}{ Ingredients, \% } \\
\hline Corn silage $^{1}$ & 34.4 & 34.4 & 34.4 & 32.4 & . \\
\hline Grass hay $^{2}$ & 25.6 & 25.6 & 25.6 & 25.6 & . \\
\hline Soybean meal & 8.2 & 9.1 & 15.8 & 21.5 & . \\
\hline Cracked dry corn & 17.7 & 14.0 & 10.9 & 9.0 & . \\
\hline Wheat midds & $\ldots$ & 8.7 & 6.8 & 5.6 & . \\
\hline Distillers corn grain & & 6.5 & 5.1 & 4.2 & \\
\hline Soyhulls & 11.8 & $\ldots$ & $\ldots$ & $\ldots$ & \\
\hline Mineral mix $\mathrm{A}^{3}$ & & 1.7 & 1.2 & 1.2 & . \\
\hline Mineral mix $B^{4}$ & 2.0 & $\ldots$ & & & \\
\hline Urea & 0.3 & $\ldots$ & 0.2 & 0.3 & . \\
\hline Limestone & $\ldots$ & $\ldots$ & $\ldots$ & 0.2 & \\
\hline \multicolumn{6}{|l|}{ Nutrients $^{5}$} \\
\hline DM \% & 59.6 & 59.6 & 60.9 & 60.8 & 0.64 \\
\hline $\mathrm{CP} \%$ & $11.9^{\mathrm{a}}$ & $16.7^{\mathrm{b}}$ & $18.1^{\mathrm{c}}$ & $20.1^{\mathrm{d}}$ & 1.33 \\
\hline Soluble $\mathrm{CP}, \%$ of $\mathrm{CP}$ & 33.5 & 31.3 & 34.8 & 31.8 & 1.60 \\
\hline $\mathrm{RDP}, \%$ of $\mathrm{CP}$ & 66.0 & 66.1 & 67.6 & 67.5 & 1.23 \\
\hline NSC, ${ }^{6} \%$ & 32.3 & 32.4 & 31.3 & 30.6 & 0.80 \\
\hline Starch, \% & 20.6 & 19.2 & 19.0 & 19.0 & 0.48 \\
\hline Sugar, \% & 4.3 & 4.1 & 4.3 & 4.8 & 0.40 \\
\hline $\mathrm{NDF}, \%$ & 44.5 & 42.1 & 41.5 & 39.7 & 2.72 \\
\hline $\mathrm{ADF}, \%$ & $28.9^{\mathrm{a}}$ & $24.7^{\mathrm{b}}$ & $25.1^{\mathrm{b}}$ & $24.5^{\mathrm{b}}$ & 0.96 \\
\hline $\mathrm{TDN}^{7,8} \%$ & 68.9 & 71.1 & 71.1 & 71.3 & \\
\hline $\mathrm{ME},{ }^{9} \mathrm{Mcal} / \mathrm{kg} \mathrm{DM}$ & 2.5 & 2.6 & 2.6 & 2.6 & \\
\hline $\mathrm{Ca}, \%$ & 0.60 & 0.51 & 0.52 & 0.56 & 0.05 \\
\hline $\mathrm{P}, \%$ & 0.38 & 0.39 & 0.39 & 0.39 & 0.01 \\
\hline $\mathrm{Mg}, \%$ & 0.13 & 0.16 & 0.13 & 0.11 & 0.03 \\
\hline $\mathrm{K}, \%$ & 1.42 & 1.35 & 1.38 & 1.38 & 0.05 \\
\hline \multicolumn{6}{|l|}{ Particle Size } \\
\hline$>19 \mathrm{~mm}, \%$ & 35.6 & 28.2 & 27.4 & 31.7 & 4.88 \\
\hline $8 \mathrm{~mm}-19 \mathrm{~mm}, \%$ & $32.0^{\mathrm{a}}$ & $42.5^{\mathrm{b}}$ & $42.2^{\mathrm{b}}$ & $40.2^{\mathrm{b}}$ & 2.59 \\
\hline$<8 \mathrm{~mm}, \%$ & $41.3^{\mathrm{a}}$ & $29.3^{\mathrm{b}}$ & $34.8^{\mathrm{c}}$ & $33.3^{b, c}$ & 1.74 \\
\hline
\end{tabular}

${ }^{\mathrm{a}, \mathrm{b}, \mathrm{c}, \mathrm{d}}$ Superscripts that differ are significant, $P \leq 0.05$.

${ }^{1}$ Corn silage contained $37.4 \% \mathrm{DM}, 34.8 \% \mathrm{NDF}, 19.8 \% \mathrm{ADF}$, and $8.5 \% \mathrm{CP}$ on DM basis.

${ }^{2}$ Grass hay contained $91.4 \% \mathrm{DM}, 69.9 \% \mathrm{NDF}, 41.5 \% \mathrm{ADF}$, and $7.7 \% \mathrm{CP}$ on DM basis.

${ }^{3}$ Contained $41.4 \%$ aragonite, $21.9 \%$ urea, $14.6 \%$ salt, $7.3 \%$ magnesium oxide, $4.8 \%$ vitamin E (125,000 IU of vitamin $\mathrm{E} / \mathrm{kg}$ ), $4.8 \%$ dicalcium phosphate, $2.4 \%$ anemia mix, $0.06 \%$ Se, $0.9 \%$ Dynamate $22 \mathrm{~S}$, and $0.7 \%$ vitamin $\mathrm{ADE}(6,000,000 \mathrm{IU}$ of vitamin $\mathrm{A} / \mathrm{kg}, 1,500,000 \mathrm{IU}$ of vitamin $\mathrm{D} / \mathrm{kg}$, and 37,000 IU of vitamin $\mathrm{E} / \mathrm{kg}$ ) as a percent DM basis.

${ }^{4}$ Contained 38.7 dicalcium phosphate, 23.9 aragonite, 11.7 salt, 7.9 Dynamate $22 \mathrm{~S}, 7.9$ magnesium oxide, 5.8 vitamin $\mathrm{E}(125,000 \mathrm{IU}$ of vitamin $\mathrm{E} / \mathrm{kg}), 0.06 \% \mathrm{Se}$, and 0.9 vitamin $\mathrm{ADE}$ (6,000,000 IU of vitamin $\mathrm{A} / \mathrm{kg}$, $1,500,000 \mathrm{IU}$ of vitamin $\mathrm{D} / \mathrm{kg}$, and $37,000 \mathrm{IU}$ of vitamin $\mathrm{E} / \mathrm{kg}$ ) as a percent DM basis.

${ }^{5} \mathrm{n}=4$ composite samples representing 36 samples per treatment ration taken during the trial.

${ }^{6}$ Nonstructural carbohydrates.

${ }^{7}$ Calculated from ingredients.

${ }^{8}$ Total digestible nutrients.

${ }^{9}$ Estimated: Metabolizable energy $(\mathrm{ME})=\mathrm{TDN} * 0.04409 * 0.82$.

were made per heifer per experimental period. Dried fecal composites were analyzed for DM, N (AOAC, 1990), and P (Fiske and Subbarrow, 1925 and Sigma Kit 670C; Sigma Chemical Co., St. Louis, MO). Urine composites were analyzed for N (AOAC, 1990), P (Fiske and Subbarrow, 1925 and Sigma Kit 670C), urea (Marsh et al., 1957), allantoin (Chen, 1989), and uric acid (Sigma Kit 686A; Sigma Chemical Co., St. Louis, $\mathrm{MO}$ ). Microbial $\mathrm{N}$ was calculated from total urinary excretion of PD according to Valadares et al. (1999).

\section{Statistical Analysis}

Nutrient content of treatment rations were analyzed by the PROC GLM procedure of SAS (1999). Least square means and standard errors were determined using the LSMEANS and STDERR statement in PROC GLM. Mean separations were determined using Tukey's multiple comparison procedure.

Dry matter intake, $\mathrm{N}$ intake, $\mathrm{N}$ excretion, total tract apparent $\mathrm{DM}$ and $\mathrm{N}$ digestibility, $\mathrm{P}$ excretion, urinary 
Table 2. Least square means for DMI, CP intake, calculated metabolizable energy intake, calculated dietary protein to metabolizable energy ratios, and calculated nonstructural carbohydrate to rumen degradable protein ratios.

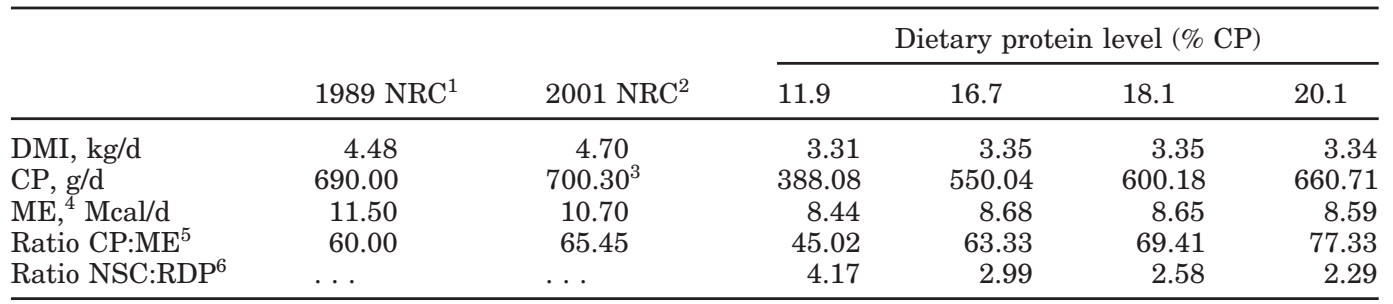

\footnotetext{
${ }^{1}$ Extrapolated from large breed growing heifers gaining $0.80 \mathrm{~kg} / \mathrm{d}$ (NRC, 1989).

${ }^{2}$ Inputs into table generator for heifers were: mature BW $650 \mathrm{~kg}$, BW $175 \mathrm{~kg}$, ADG $800 \mathrm{~g} / \mathrm{d}$, BCS 2.80 , age $6.2 \mathrm{mo}$, and days pregnant 0 (NRC, 2001).

${ }^{3} \mathrm{NRC}$ (2001) CP intake requirement (from the heifer requirement table generator), is the sum of RDP and RUP when perfectly balanced.

${ }^{4}$ Estimated: Metabolizable energy $(\mathrm{ME})=\mathrm{TDN} * 0.04409 * 0.82$.

${ }^{5} \mathrm{~g}$ of $\mathrm{CP}$ per Mcal of ME.

${ }^{6}$ Ratio of nonstructural carbohydrates to rumen degradable protein, $\mathrm{g}$ of NSC per $\mathrm{g}$ of RDP.
}

excretion of urea, allantoin and uric acid, and microbial $\mathrm{N}$ calculated from urinary excretion of $\mathrm{PD}$ were analyzed using a SATTERTH model statement in the PROC MIXED procedure of SAS (Littell et al., 1996). The model included treatment ration and experimental period as fixed effects with experimental period repeated.

The $\mathrm{pH}$ of rumen fluid, ammonia $\mathrm{N}$ concentrations of rumen fluid, molar concentrations and proportions of VFA in rumen fluid, and plasma urean nitrogen (PUN) were analyzed over time using a SATTERTH model statement in the PROC MIXED procedure of SAS (Littell et al., 1996). The model included treatment ration, time point, and experimental period as fixed effects with time point repeated. Ammonia $\mathrm{N}$ concentrations of rumen fluid possessed a treatment ration $\times$ time point interaction, which was included in the model. Mean rumen $\mathrm{pH}$ and ammonia $\mathrm{N}$ were calculated from the average of the time points measured.

Simple, autoregressive one, and compound symmetry covariance structures were utilized in the analysis depending on low values received for goodness of fit measures, Akaike's Information Criterion and Schwartz's Bayesian Criterion. Least square means and standard errors were determined through the LSMEANS statement in the PROC MIXED procedure of SAS (Littell et al., 1996). Mean separations were determined using Tukey's multiple comparison procedure.

\section{RESULTS AND DISCUSSION}

Treatment ration CP concentration increased, whereas ME calculated from total digestible nutrients remained constant (Table 1). Soluble CP and RDP, as a percentage of dietary $\mathrm{CP}$, were similar across treatment rations by design. The lowest dietary protein level ratio (11.9\% CP), had differences in the 8- to 19-mm particle size, less than 8-mm particle size, and ADF despite similar forage components as compared to other treatment rations. These differences were primarily the result of the inclusion of soyhulls in this treatment ration (Table 1).

Heifers were fed once daily and rapidly consumed the entire treatment ration before being let out to a paved exercise lot. We speculate that rumen $\mathrm{pH}, \mathrm{VFA}$ production, and ammonia levels at certain hours could be influenced by this feeding or eating pattern (Figures 1 and 2).

Actual DMI, daily CP intake, ME intake, and CP:ME are calculated in Table 2. Calculated CP:ME of the treatment rations were $45.0,63.3,69.4$, and $77.3 \mathrm{~g} \mathrm{CP}$ per Mcal of ME. The 1989 and 2001 NRC requirements

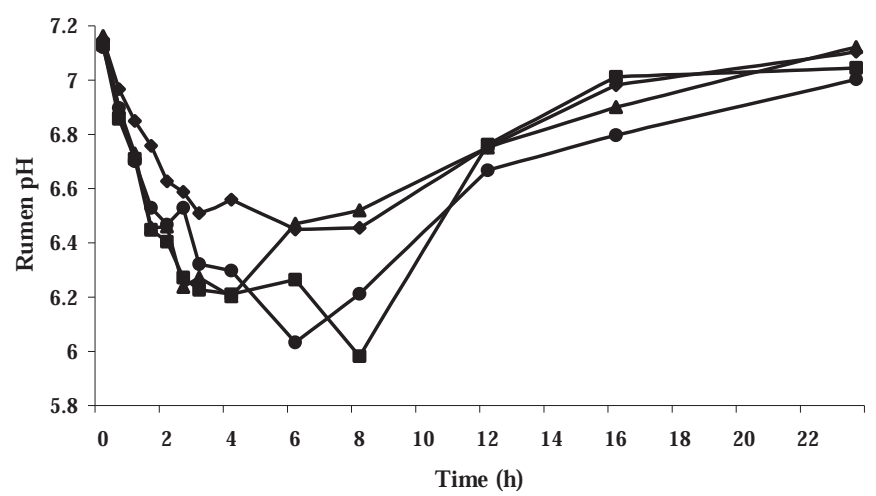

Figure 1. Rumen $\mathrm{pH}$ of Holstein heifers fed differing ratios of dietary protein to metabolizable energy ( $\mathrm{g}$ of CP per Mcal of ME) from 153 to $196 \mathrm{~kg} \mathrm{BW}$. Rations contained 11.9\% CP $\bullet, 16.7 \% \mathrm{CP}$ $\mathbf{\square}, 18.1 \% \mathrm{CP} \boldsymbol{\Delta}$, and $20.1 \% \mathrm{CP}$. 


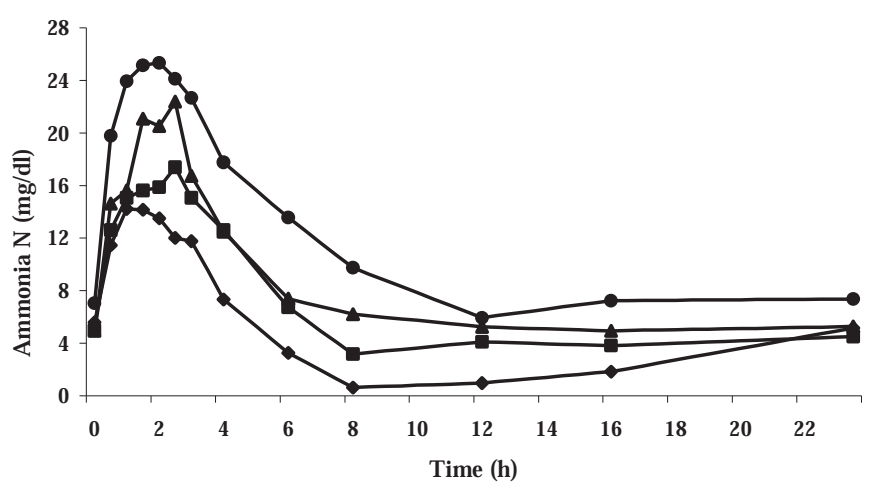

Figure 2. Ammonia $\mathrm{N}$ concentrations $(\mathrm{mg} / \mathrm{dl})$ of Holstein heifers fed increasing levels of CP from 153 to $196 \mathrm{~kg}$ of BW. Rations contained $11.9 \% \mathrm{CP} \bullet, 16.7 \% \mathrm{CP} \mathbf{\square}, 18.1 \% \mathrm{CP} \boldsymbol{\Lambda}$, and $20.1 \% \mathrm{CP} \bullet$

(from the heifer requirement table generator; NRC, 2001) are provided (Table 2) for reference. Heifers averaged $0.54 \pm 0.10 \mathrm{~kg}$ gain per day, which is in contrast to previous findings with similar treatment rations and BW heifers (Gabler and Heinrichs, 2003). The decreased animal performance in the present study as compared to Gabler and Heinrichs (2003) may be consequences of the stress of frequent intensive sampling and collections, along with frequent diet changes.

Rumen $\mathrm{pH}$ was not affected by increasing CP levels (Table 3). Similar NSC concentrations across treatment rations support the lack of effect of treatments on mean rumen $\mathrm{pH}$. Large fluctuations in rumen $\mathrm{pH}$ post feeding (Figure 1) can be explained by the rapid rate of consumption of the diet each day and the diet being rela- tively high in concentrate (60:40 forage-to-concentrate ratio; $\mathbf{F}: \mathbf{C})$.

Mean rumen ammonia $\mathrm{N}$ concentrations (Table 3) increased with increasing CP levels. An in vitro study by Satter and Slyter (1974) reported that $5 \mathrm{mg} / \mathrm{dl}$ of rumen ammonia $\mathrm{N}$ is required for maximum rumen microbial growth. Others (Mehrez et al., 1977) found increased rates of rumen fermentation and substrate degradation when rumen ammonia $\mathrm{N}$ concentration reached $21.4 \mathrm{mg} / \mathrm{dl}$. Mehrez et al. (1977) assumed increased fermentation and degradation of substrates is the result of increased rumen microbial activity and growth. In vitro and mature cattle studies reporting ranges of rumen ammonia $\mathrm{N}$ concentrations for optimal microbial protein synthesis are inconsistent, likely due to the influence that energy availability of the diet has on microbial growth. No data linking rumen ammonia $\mathrm{N}$ concentrations and microbial growth is available for Holstein heifers between 153 and $196 \mathrm{~kg}$ of BW.

Peak rumen ammonia $\mathrm{N}$ concentrations were between 2 and $2.5 \mathrm{~h}$ postfeeding (Figure 2 ). Using a rumen ammonia $\mathrm{N}$ concentration value of less than $5 \mathrm{mg} / \mathrm{dl}$ as indicative of suboptimal availability of ammonia for microbial growth, the 11.9 and $16.7 \% \mathrm{CP}$ levels each remained suboptimal 20 and $18 \mathrm{~h}$ of the $24 \mathrm{~h}$ sampling day, respectively, while the $18.1 \% \mathrm{CP}$ level remained suboptimal $1 \mathrm{~h}$, and $20.1 \% \mathrm{CP}$ level had no recorded rumen ammonia $\mathrm{N}$ below $5 \mathrm{mg} / \mathrm{dl}$. From $12 \mathrm{~h}$ postfeeding until the next feeding, rumen ammonia $\mathrm{N}$ concentrations were maintained at very low levels due to the rapid consumption of the diet.

Similar to rumen ammonia N concentration, PUN concentrations (Table 3 ) increased with increasing $\mathrm{CP}$

Table 3. Rumen fermentation of Holstein heifers fed increasing CP levels from 153 to $196 \mathrm{~kg}$ of BW.

\begin{tabular}{|c|c|c|c|c|c|}
\hline & \multicolumn{4}{|c|}{ Dietary protein level (\% CP) } & \multirow[b]{2}{*}{$\mathrm{SE}$} \\
\hline & 11.9 & 16.7 & 18.1 & 20.1 & \\
\hline \multicolumn{6}{|l|}{$\mathrm{pH}$} \\
\hline Mean & 6.75 & 6.56 & 6.63 & 6.58 & 0.12 \\
\hline Lowest value & 6.32 & 5.76 & 6.15 & 5.99 & 0.07 \\
\hline \multicolumn{6}{|l|}{ Ammonia N } \\
\hline Mean mg/dl & $7.84^{\mathrm{a}}$ & $10.11^{\mathrm{ab}}$ & $12.11^{\mathrm{b}}$ & $16.12^{\mathrm{c}}$ & 0.72 \\
\hline Total VFA, mmol/ml & 71.09 & 70.74 & 70.88 & 77.64 & 3.45 \\
\hline \multicolumn{6}{|l|}{ VFA, molar proportions } \\
\hline Acetate & 63.50 & 65.32 & 64.69 & 64.13 & 1.23 \\
\hline Propionate & 19.64 & 19.02 & 20.67 & 19.68 & 1.08 \\
\hline Butyrate & 10.97 & 10.91 & 9.27 & 10.23 & 0.56 \\
\hline Isovalerate & 1.39 & 1.42 & 1.81 & 1.73 & 0.25 \\
\hline Valerate & 1.04 & 1.82 & 1.42 & 1.76 & 0.29 \\
\hline Isobutyrate & 1.32 & 1.19 & 1.27 & 1.11 & 0.08 \\
\hline $\mathrm{A}: \mathrm{P}$ ratio $^{1}$ & 3.30 & 3.52 & 3.25 & 3.31 & 0.23 \\
\hline \multicolumn{6}{|l|}{ Plasma Urea N } \\
\hline Mean mg/dl & $10.12^{\mathrm{x}}$ & $12.42^{\mathrm{xy}}$ & $14.18^{\mathrm{xy}}$ & $16.68^{y}$ & 1.73 \\
\hline
\end{tabular}

${ }^{\mathrm{a}, \mathrm{b}, \mathrm{c}}$ Superscripts that differ are significant, $P \leq 0.05$.

${ }^{\mathrm{x}, \mathrm{y}}$ Superscripts that differ are significant, $P \leq 0.10$.

${ }^{1}$ Ratio of acetate to propionate. 
Table 4. Total tract apparent digestibility of treatment rations, $\mathrm{N}$ balance, and $\mathrm{P}$ excretion of Holstein heifers fed increasing dietary protein levels from 153 to $196 \mathrm{~kg}$ of BW.

\begin{tabular}{|c|c|c|c|c|c|}
\hline & \multicolumn{4}{|c|}{ Dietary protein level (\% CP) } & \multirow[b]{2}{*}{$\mathrm{SE}$} \\
\hline & 11.9 & 16.7 & 18.1 & 20.1 & \\
\hline Apparent DM digestibility ${ }^{1}, \%$ & 76.36 & 78.02 & 77.29 & 74.94 & 0.95 \\
\hline $\mathrm{N}$ intake, g/d & $62.09^{\mathrm{a}}$ & $88.00^{\mathrm{b}}$ & $96.03^{\mathrm{c}}$ & $105.71^{\mathrm{c}}$ & 6.04 \\
\hline Fecal $N$ excretion, $g / d$ & 18.22 & 20.00 & 19.30 & 20.28 & 1.21 \\
\hline Urinary $\mathrm{N}$ excretion, g/d & $22.72^{\mathrm{a}}$ & $34.02^{\mathrm{ab}}$ & $46.69^{\mathrm{b}}$ & $62.22^{\mathrm{c}}$ & 3.50 \\
\hline Total N excretion, $\mathrm{g} / \mathrm{d}$ & $40.63^{\mathrm{a}}$ & $54.54^{\mathrm{ab}}$ & $66.01^{\mathrm{b}}$ & $82.26^{\mathrm{c}}$ & 4.26 \\
\hline Apparent $\mathrm{N}$ digestibility ${ }^{1}, \%$ & $69.59^{\mathrm{a}}$ & $77.34^{\mathrm{b}}$ & $79.68^{\mathrm{b}}$ & $80.72^{\mathrm{b}}$ & 1.80 \\
\hline $\mathrm{N}$ retained, $\% \mathrm{~N}$ intake & 30.16 & 37.74 & 32.31 & 22.16 & 6.67 \\
\hline Urine Urea excretion, g/d & $13.42^{\mathrm{a}}$ & $23.93^{\mathrm{b}}$ & $36.0^{\mathrm{cb}}$ & $47.38^{\mathrm{d}}$ & 2.76 \\
\hline Urine Urea, \% Urine $\mathrm{N}$ & $57.44^{\mathrm{a}}$ & $70.67^{\mathrm{b}}$ & $77.55^{\mathrm{b}}$ & $75.85^{\mathrm{b}}$ & 1.84 \\
\hline $\mathrm{P}$ intake, $\mathrm{g} / \mathrm{d}$ & 12.68 & 13.10 & 12.86 & 12.90 & 0.66 \\
\hline Fecal P excretion, g/d & 6.16 & 5.59 & 5.05 & 5.82 & 0.94 \\
\hline Urine $P$ excretion, $g / d$ & 0.84 & 2.23 & 2.19 & 2.26 & 0.63 \\
\hline Total P excretion, g/d & 7.00 & 7.82 & 7.24 & 8.08 & 0.72 \\
\hline $\mathrm{P}$ excretion, \% $\mathrm{P}$ intake & 54.93 & 60.09 & 56.52 & 62.35 & 4.08 \\
\hline
\end{tabular}

levels. The observed levels of PUN were anticipated, as these have been related to increased CP intake (Hall et al., 1995). A growth trial (Gabler and Heinrichs, 2003) utilizing similar diets and heifers as the present study also reported similar mean PUN concentrations in samples taken $3 \mathrm{~h}$ postfeeding every $28 \mathrm{~d}$.

Apparent total tract DM digestibility values were similar for all diets. Casper et al. (1994) hypothesized that identifying a correct NSC:RDP may increase efficiency of fermentation. The lack of response in total tract DM digestibility of the higher CP levels may have been due to low NSC:RDP resulting from excess RDP or not enough rumen degradable carbohydrates.

Increasing CP levels increased urinary $\mathrm{N}$, however, did not affect fecal $\mathrm{N}$ excretion. Total tract $\mathrm{N}$ digestibility was lowest for the lowest CP level $(11.9 \% \mathrm{CP})$. The majority of $\mathrm{N}$ excreted occurred via urine; consequently the increase observed in urinary $\mathrm{N}$ excretion influenced total $\mathrm{N}$ excretion such that total $\mathrm{N}$ excretion also was highest at the $20.1 \% \mathrm{CP}$ level. These results agree with Devant et al. (2000) and Marini and Van Amburgh (2001), who reported no effects of increasing dietary CP concentrations on fecal $\mathrm{N}$ excretion, but linear effects in total tract apparent $\mathrm{N}$ digestibility, urinary $\mathrm{N}$ excretion, and total $\mathrm{N}$ excretion.

The $20.1 \% \mathrm{CP}$ level treatment ration resulted in $16.8 \%$ greater $\mathrm{N}$ intake than the $16.7 \% \mathrm{CP}$ level, yet total N excretion for the $20.1 \%$ CP level was $33.7 \%$ greater than that of the $16.7 \% \mathrm{CP}$ level. Heifers fed the $18.1 \% \mathrm{CP}$ level had $8.4 \%$ greater $\mathrm{N}$ intake than the $16.7 \% \mathrm{CP}$ level, but excreted $17.4 \%$ more N. The disparity between $\mathrm{N}$ intake increases and total $\mathrm{N}$ excretion could be explained by an imbalance from a lack of energy yielding nutrients for microbial uptake of ammo- nia for the 20.1 and $18.1 \% \mathrm{CP}$ levels resulting in inefficient utilization and absorption of nutrients or that these levels are higher than the overall requirements of the animal.

Urinary excretion of urea increased with increasing CP levels (Table 4). These results are consistent with Archibeque et al. (2001) who reported linear increases in urinary urea with increased $\mathrm{N}$ intake. Urinary excretion of urea as a percentage of urine $\mathrm{N}$ excreted increased with increasing CP levels, but plateaued at the higher CP levels.

By design, $\mathrm{P}$ intake was constant across treatment rations (Table 4). Fecal, urinary, total $\mathrm{P}$ excretion, and total excretion of $\mathrm{P}$ as a percent of $\mathrm{P}$ intake were not affected by treatment. Little data is available on fecal excretion of $\mathrm{P}$ for heifers between 153 and $196 \mathrm{~kg}$ of BW and consuming $P$ intakes of $12.9 \pm 0.2 \mathrm{~g} / \mathrm{d}$. Fecal $\mathrm{P}$ excretion averaged $29.7 \pm 6.7 \%$ higher than values calculated through equations provided by Challa et al. (1989) who utilized bull calves and did not feed $\mathrm{P}$ intakes as low as the present study. The disparity between studies and the overall lack of data on P excretion by growing heifers calls for future research in this area.

Measurement of microbial synthesis in the rumen or outflow of microbial cells into the intestine by use of markers and intestinal cannulated animals is time consuming, expensive, and often of low precision (Kanjanapruthipong and Leng, 1998). Topps and Elliott (1965) showed that urinary excretion of PD provides a sound indicator and noninvasive method of predicting microbial synthesis that leaves the rumen and is digested in the intestine of ruminants. Allantoin and uric acid are the only PD present in cattle urine because the high xanthine oxidase activity in the blood and tissue con- 
Table 5. Urinary excretion of purine derivatives and calculated microbial $\mathrm{N}$ of Holstein heifers fed increasing dietary protein levels from 153 to $196 \mathrm{~kg}$ of BW.

\begin{tabular}{|c|c|c|c|c|c|}
\hline & \multicolumn{4}{|c|}{ Dietary protein level (\% CP) } & \multirow[b]{2}{*}{$\mathrm{SE}$} \\
\hline & 11.9 & 16.7 & 18.1 & 20.1 & \\
\hline Allantoin, g/d & $7.83^{\mathrm{a}}$ & $8.16^{\mathrm{ab}}$ & $9.01^{\mathrm{ab}}$ & $10.75^{\mathrm{b}}$ & 1.05 \\
\hline Uric acid, g/d & $0.33^{\mathrm{a}}$ & $0.22^{\mathrm{b}}$ & $0.20^{\mathrm{b}}$ & $0.26^{\mathrm{ab}}$ & 0.07 \\
\hline Total PD, ${ }^{1} \mathrm{~g} / \mathrm{d}$ & $8.02^{\mathrm{a}}$ & $8.38^{\mathrm{ab}}$ & $9.35^{\mathrm{ab}}$ & $11.01^{b}$ & 1.02 \\
\hline Microbial N, ${ }^{2} \mathrm{~g} / \mathrm{d}$ & $24.07^{\mathrm{a}}$ & $25.78^{\mathrm{a}}$ & $30.31^{\mathrm{ab}}$ & $38.05^{b}$ & 4.77 \\
\hline
\end{tabular}

verts xanthine and hypoxanthine into uric acid before excretion (Valadares et al., 1999). Martin-Orue et al. (2000) utilizing growing Holstein heifers (initial BW $306 \mathrm{~kg}$ ) reported that urinary PD closely reflected microbial $\mathrm{N}$ production as determined by digesta flow measurements.

Urinary excretion of the PD allantoin increased with increasing CP levels (Table 5), with the $20.1 \%$ CP level resulting in significantly greater allantoin than the lowest CP level. Urinary excretion of the PD uric acid was altered, with the CP levels of 11.9 and $20.1 \%$ resulting in the highest excretion $(\mathrm{g} / \mathrm{d})$ of uric acid. Urinary excretion of allantoin constituted on average $97 \%$ of the total PD excreted in the present study, which is consistent with Devant et al. (2000). Because of the effect observed for urinary excretion of allantoin, total urinary excretion of PD generally increased with increasing CP levels. This is in contrast to Devant et al. (2000) who reported no effect on total urinary excretion of $\mathrm{PD}$ with increasing dietary $\mathrm{CP}$ intakes in crossbred beef heifers (100 to $230 \mathrm{~kg}$ of BW) fed ad libitum diets containing 30 to $70 \mathrm{~F}: \mathrm{C}$, higher NSC, lower NDF, and gaining greater than $1.17 \mathrm{~kg} / \mathrm{d}$.

Microbial $\mathrm{N}$ absorbed in the small intestine was calculated from total urinary excretion of PD (Table 5) using equations described by Valadares et al. (1999). Calculated microbial $\mathrm{N}$ increased with increasing $\mathrm{CP}$ levels. By design, treatment rations contained the same F:C, similar particle size distributions, and same DMI as a percentage of BW, thus passage rates should likely not have been altered. Consequently, it can be assumed that increased calculated microbial $\mathrm{N}$ absorbed in the small intestine corresponds to increased microbial protein synthesis in the rumen. Increases in rumen ammonia concentrations and corresponding increases in calculated microbial $\mathrm{N}$ demonstrate the availability of adequate ammonia $\mathrm{N}$ for microbial growth with increasing CP levels.

\section{CONCLUSIONS}

Feeding a diet with $11.9 \%$ CP to prepubertal Holstein heifers resulted in depressed $\mathrm{N}$ digestibility and de- creased calculated rumen microbial $\mathrm{N}$ production. Feeding a CP level of $20.1 \%$ increased calculated microbial $\mathrm{N}$, likely demonstrating the availability of adequate ammonia $\mathrm{N}$ needed for microbial growth. The highest CP level (20.1\%) was found to be economically and environmentally costly due to high $\mathrm{N}$ excretion and no difference in total tract apparent DM digestibility, possibly the result of too low of a NSC:RDP. Lower than expected ADG were observed in this study, which could influence some outcomes. Holstein heifers between 153 and $196 \mathrm{~kg}$ consuming a diet at $2.0 \% \mathrm{BW}$ as DMI containing a $\mathrm{CP}$ level of $16.7 \%$ (CP:ME ratio of $63.3 \mathrm{~g}$ of $\mathrm{CP}$ per Mcal of ME) achieved a better synergistic relationship of dietary protein to energy than at other levels in this experiment.

\section{ACKNOWLEDGMENTS}

The authors wish to thank Agway Incorporated for partial funding along with Maria Long, Trent Schriefer, Keith Leismeister, Karen Groner, and Gabe Mignot for laboratory and technical assistance.

\section{REFERENCES}

Archibeque, S. L., J. C. Burns, and G. B. Huntingdon. 2001. Urea flux in beef steers: Effects of forage species and nitrogen fertilization. J. Anim. Sci. 79:1937-1943.

Association of Official Analytical Chemists. 1990. Official Methods of Analysis. 15th ed. AOAC, Arlington, VA.

Broderick, G. A., and J. H. Kang. 1980. Automated simultaneous determination of ammonia and total amino acids in ruminal fluid and in vitro media. J. Dairy Sci. 63:64-75.

Casper, D. P., D. J. Schingoethe, M. J. Brouk, and H. A. Maiga. 1994. Nonstructural carbohydrates and undegradable protein sources in the diet: Growth responses of dairy heifers. J. Dairy Sci. 77:2595-2604.

Challa, J., G. D. Braithwaite, and M. S. Dhanoa. 1989. Phosphorus homeostasis in growing calves. J. Agric. Sci. Camb. 112:217-226.

Chen, X. B. 1989. Excretion of purine derivatives by sheep and cattle and its use for estimation of absorbed/microbial protein. Ph.D. Dissertation. University of Aberdeen, Aberdeen, Scotland.

Devant, M., A. Ferret, J. Gasa, S. Calsamiglia, and R. Casals. 2000. Effects of protein concentration and degradability on performance, ruminal fermentation, and nitrogen metabolism in rapidly growing heifers fed high concentrate diets from 100 to $230 \mathrm{~kg}$ body weight. J. Anim. Sci. 78:1667-1676. 
Dubois, M., K. A. Gilles, J. K. Hamilton, P. A. Rebers, and F. Smith. 1956. Colorimetric method for determination of sugars and related substances. Anal. Chem. 28:350.

Edwards, J. S., and E. E. Bartley. 1979. Soybean meal and Starea for microbial protein synthesis or milk production with rations above thirteen percent natural protein. J. Dairy Sci. 62:732-739.

Fiske, C. H., and Y. Subbarrow. 1925. The colometric determination of phosphate. J. Biol. Chem. 66:375-400.

Gabler, M. T., and A. J. Heinrichs. 2003. Increasing dietary protein to metabolizable energy ratios on feed efficiency, structural growth, and body condition score of prepubertal Holstein heifers. J. Dairy Sci. 86:268-274.

Hall, J. B., R. B. Staigmiller, R. A. Bellows, R. E. Short, W. M. Mosely, and S. E. Bellows. 1995. Body composition and metabolic profiles associated with puberty in beef heifers. J. Anim. Sci. 73:34093420 .

Holm, J., B. A. Drews, and N. G. Asp. 1986. A rapid method for the analysis of starch. Starch/die starke. 7:224-226.

Kanjanapruthipong, J., and R. A. Leng. 1998. Purine derivatives excreted in urine as an indicator estimating microbial yield from the rumen: A review. Austr. J. Agric. Res. 11:209-216.

Krishnamoorthy, U., T. V. Muscato, C. J. Sniffen, and P. J. Van Soest. 1982. Nitrogen fractions in selected feedstuffs. J. Dairy Sci. 65:217-225.

Krishnamoorthy, U., C. J. Sniffen, M. D. Stern, and P. J. Van Soest. 1983. Evaluation of a mathematical model of rumen digestion and an in vivo simulation of rumen proteolysis to estimate rumen undegradable nitrogen content of feedstuffs. Br. J. Nutr. 50:55-63.

Lammers, B. P., D. R. Buckmaster, and A. J. Heinrichs. 1996. A simple method for the analysis of particle sizes of forage and total mixed rations. J. Dairy Sci. 79:922-928.

Littell, R. C., G. A. Milliken, W. W. Stroup, and R. D. Wolfinger. 1996. SAS System for mixed models. SAS Inst. Inc., Cary, NC

Marini, J. C., and M. E. Van Amburgh. 2001. Effect of different levels of protein on nitrogen metabolism of heifers. J. Dairy Sci. 84(Suppl. 1):160-161. (Abstr.)

Marsh, W. H., B. Fingerhut, and E. Kirsch. 1957. Determination of urea with the diacetyl method and an automatic dialyzing apparatus. Am. J. Clin. Pathol. 28:681-688.

Martin-Orue, S. M., J. Balcells, J. A. Guada, and M. Fondevila. 2000. Microbial nitrogen production in growing heifers: Direct measure- ment of duodenal flow of purine bases versus urinary excretion of purine derivatives as estimation procedures. Anim. Feed Sci. Tech. 88:171-188.

Mehrez, A. Z., E. R. Orskov, and I. McDonald. 1977. Rates of rumen fermentation in relation to ammonia concentration. Br. J. Nutr. 38:437-443.

National Research Council. 2001. Nutrient Requirements of Dairy Cattle. 7th Rev. ed. Natl. Acad. Sci., Washington, DC.

National Research Council. 1996. Nutrient Requirements of Beef Cattle. 6th Rev. ed. Natl. Acad. Sci., Washington, DC.

National Research Council. 1989. Nutrient Requirements of Dairy Cattle. 6th Rev. ed. Natl. Acad. Sci., Washington, DC.

Nocek, J. E., and J. B. Russell. 1988. Protein and energy as an integrated system. Relationship of ruminal protein and carbohydrate availability to microbial synthesis and milk production. J. Dairy Sci. 71:2070-2107.

Oldham, J. D. 1984. Protein-energy interrelationships in dairy cows. J. Dairy Sci. 67:1090-1114.

SAS/STAT. 1999. User's Guide, Version 8.0. 1999. SAS Inst. Inc., Cary, NC

Satter, L. D., and L. L. Slyter. 1974. Effect of ammonia concentration on ruminal microbial protein production in vitro. Br. J. Nutr. 32:199-208.

Smith, D. 1981. Removing and analyzing carbohydrates from plant tissues. Wisconsin Agric. Exp. Stn. Rep. No. R2107, Madison, WI.

Topps, J. H., and R. C. Elliott. 1965. Relationship between concentrations of ruminal nucleic acids and excretion of purine derivatives by sheep. Nature 205:498-499.

Valadares, R. D., G. A. Broderick, S. C. Valadares Filho, and M. K. Clayton. 1999. Effect of replacing alfalfa silage with high moisture corn on ruminal protein synthesis estimated from excretion of total purine derivatives. J. Dairy Sci. 82:2686-2696.

Veira, D. M., G. K. Macleod, J. H. Burton, and J. B. Stone. 1980a. Nutrition of the weaned Holstein calf. I. Effect of dietary protein level on rumen metabolism. J. Anim. Sci. 50:937-944.

Veira, D. M., G. K. Macleod, J. H. Burton, and J. B. Stone. 1980b. Nutrition of the weaned Holstein calf. II. Effect of dietary protein level on nitrogen balance, digestibility, and feed intake. J. Anim. Sci. 50:945-951.

Yang, C. M. J., and G. A. Varga. 1989. Effect of three concentrate feeding frequencies on rumen protozoa, rumen digesta kinetics, and milk yield in dairy cows. J. Dairy Sci. 72:950-957. 